\title{
Morphology Character Result in Standard Format
}

National Cancer Institute

\section{Source}

National Cancer Institute. Morphology Character Result in Standard Format. NCI

Thesaurus. Code C117613.

The standard character or string for representation and reporting of morphology data. 